\title{
ANTIMICROBIAL AND ANTIOXIDANT ACTIVITY OF BACTERIAL ENDOPHYTES ISOLATED FROM LEAVES OF THE MANGROVE PLANT Rhizophora stylosa
}

\author{
Ton That Huu Dat", Phung Thi Thuy Oanh, Vu Thi Thanh Tam, Hoang Le Tuan Anh \\ Mientrung Institute for Scientific Research, VAST, Vietnam \\ Received 6 October 2019, accepted 27 December 2019
}

\begin{abstract}
Mangroves are the most productive ecosystems and contain highly diverse plants and microbial communities. Mangrove endophytes are proved to be a rich source of bioactive secondary metabolites. The biological molecules produced by endophytes play an important role in protection of mangrove plants against herbivores, insects as well as pathogens. The present study aimed to isolate the endophytic bacteria from the mangrove plant Rhizophora stylosa and screen antimicrobial and antioxidant activity of ethyl acetate extracts from the isolated endophytic bacteria. A total of 64 endophytic bacterial strains from $R$. stylosa leaves were isolated, of which ethyl acetate extracts of 14 isolated endophytic strains showed antimicrobial activity against at least one of reference microorganisms Escherichia coli ATCC 25922, Pseudomonas aeruginosa ATCC 25923, Bacillus subtilis ATCC 27212, Staphylococcus aureus ATCC 12222 and Candida albicans ATCC 7754 with MIC values from 32 to $512 \mu \mathrm{g} / \mathrm{ml}$. Among them, four strains showed activity against one reference microorganism, five strains showed activity against two reference microorganisms, four strains showed activity against three reference microorganisms, and one strain showed activity against four reference microorganisms. Additionally, the ethyl acetate extracts of 12 isolated endophytic bacteria showed ATBS and DPPH radical scavenging activity with scavenging values from $36.3 \pm 2.6 \%$ to $71.5 \pm 6.6 \%$ and from $26.2 \pm 3.3 \%$ to $57.4 \pm 5.8 \%$, respectively. The identification of the five most active endophytic bacteria by $16 \mathrm{~S}$ rRNA sequences revealed that the endophytes belonged to four genera, including Bacillus, Streptomyces, Pseudovibrio and Pseudomonas. The obtained results suggest that the endophytic bacteria from mangrove plants are a promising reservoir of antimicrobial and antioxidant agents.
\end{abstract}

Keywords: Rhizophora stylosa, antimicrobial activity, antioxidant activity, endophytic bacteria, mangroves.

Citation: Ton That Huu Dat, Phung Thi Thuy Oanh, Vu Thi Thanh Tam, Hoang Le Tuan Anh, 2019. Antimicrobial and antioxidant activity of bacterial endophytes isolated from leaves of the mangrove plant Rhizophora stylosa. Academia Journal of Biology, 41(4): 91-99. https://doi.org/10.15625/2615-9023/v41n4.14675.

*Corresponding author email: huudat96@gmail.com

(C2019 Vietnam Academy of Science and Technology (VAST) 


\section{INTRODUCTION}

Endophytes were defined as "microbes that colonize living, internal tissues of plants without causing any immediate, overt negative effects" (Stone et al., 2000). It is reported that endophytes can be transmitted over generations through the tissue of the host, seed or plant propagules (Carroll, 1988). Endophytic bacteria are able to prevent the deleterious effects on certain pathogenic organisms. These microbes function as a biological defense for the plant against phytopathogens by producing secondary metabolites that inhibit phytopathogens or by inducing host defense mechanisms (Alvin et al., 2014). In addition, endophytes play important roles in promotion of plant growth by producing phytohormones (Tudzynski, 1997), synthesizing of siderophores (O'Sullivan \& O'Gara, 1992), fixing nitrogen, solubilizing minerals (Richardson et al., 2009), suppressing ethylene (Glick et al., 1998) or assisting phytoremediation (Ryan et al., 2008).

Mangrove ecosystem is characterized by periodic tidal flooding and provides unique environmental characteristics for developing diverse groups of microorganisms (Sivaramakrishnan et al., 2006, Thatoi et al., 2013). Although the mangrove ecosystem is rich in microbial diversity, the described species have been less than 5\%. Furthermore, their ecological role and their technological potential are poorly understood (Thatoi et al., 2013). Interestingly, recent studies reveal that the endophytic bacteria from mangrove plants are an important source of bioactive secondary metabolites. The secondary compounds derived from endophytes of mangrove plants are structurally diverse and pharmacologically active. These known compounds from mangrove plant endophytes include terpenes, chromones, coumarins, polyketides, alkaloids, and peptides (Kui-Wu et al., 2014; Xu, 2015; Ancheeva et al., 2018). These compounds exhibit a broad spectrum of biological properties such as antioxidant, cytotoxic, antifungal, antibacterial, $\alpha$-glucosidase, acetylcholinesterase, antivirus (Kui-Wu et al.,
2014; Xu, 2015; Ancheeva et al., 2018; Zhou et al., 2018; Manganyi et al., 2019).

With the length of coastline up to 3260 $\mathrm{km}$, coastal mangroves are among the most productive and biologically important ecosystems in Vietnam (e.g., habitat for animal and vegetation species, medicinal sources, carbon storage and coastal protection from storm events). Regarding medicinal potential from Vietnamese mangrove microorganisms, a few studies on the antimicrobial activity of mangrove microorganisms have been reported (Hong \& Phuong, 2013; Dat et al., 2019). Herein, the present study isolated and screened antimicrobial and antioxidant bacterial endophytes from the mangrove plant $R$. stylosa for discovery of potential medicinal sources from Vietnamese mangrove endophytic bacteria.

\section{MATERIALS AND METHODS}

\section{Sample plant collection}

The plant $R$. stylosa was collected in the mangrove forest Canh Duong, Phu Loc, Thua Thien Hue. The samples were contained in sterile bags and transferred immediately to the laboratory for isolation of bacterial endophytes.

\section{Isolation of endophytic bacteria from leaves of $R$. stylosa}

The fresh plant leaves were washed in running water to remove soil particles. The sample surface was then sterilized by sequential immersion in $70 \%$ ethanol for 5 $\mathrm{min}$ and sodium hypochlorite for $10 \mathrm{~min}$. The samples then washed three times in sterile distilled water to remove surface sterilizing agents before being soaked in $10 \%$ sodium bicarbonate. The samples were cut into small pieces and placed on nutrient agar (Himedia) and ISP medium No. 4 (Himedia) (Hoai et al., 2018). The plates were incubated for $3-5$ days at $37^{\circ} \mathrm{C}$ for the growth of endophytic bacteria. Representative bacterial isolates with different colony morphotypes were selected, pure cultured, and stored with $20 \%$ glycerol (v/v) at $-80^{\circ} \mathrm{C}$. 


\section{Preparation of ethyl acetate extracts}

The endophytic bacterial strains were cultivated in $500 \mathrm{~mL}$ nutrient broth at $37^{\circ} \mathrm{C}$, $150 \mathrm{rpm}$ for 7 days. The fermentation broths were extracted with ethyl acetate (5 times) and then were evaporated under reduced pressure to yield ethyl acetate extracts.

\section{Screening antimicrobial activity of the extracts}

The ethyl acetate extracts of endophytic bacteria were tested against five reference microorganisms, including the Gram-positive bacteria (S. aureus ATCC12222, B. subtilis ATCC27212), the Gram-negative bacteria ( $P$. aeruginosa ATCC25923, E. coli ATCC25922) and the yeast $C$. albicans ATCC7754. Antimicrobial activity of the ethyl acetate extracts against reference microorganisms was determined as minimum inhibition concentration (MIC) values that recorded by the microdilution method (Dat et al., 2018). MIC value is the lowest concentration of the extracts that completely inhibits the growth of microorganisms.

\section{Screening antioxidant activity of the extracts}

\section{ABTS radical scavenging assay}

The ABTS radical scavenging activity of the extracts was determined by measuring the decrease in absorbance of ABTS radical solution in the presence of the extracts. Briefly, two solutions ABTS $7 \mathrm{mM}$ and potassium persulfate $2.45 \mathrm{mM}$ were mixed and allowed to stand in the dark at room temperature for $16 \mathrm{~h}$ before use in order to produce ABTS radical solution. The ABTS radical solution was then diluted with ethanol to give an absorbance of $0.700 \pm 0.02$ at 734 $\mathrm{nm}$. Ten microliters of each extract (500 $\mu \mathrm{g} / \mathrm{ml}$ ) were added to $190 \mu \mathrm{l}$ of ABTS radical solution in 96 well plates. The solution incubated at room temperature for $10 \mathrm{~min}$ and then the absorbance of the reaction was recorded at $734 \mathrm{~nm}$ on a microplate reader. Ascorbic acid was used as positive control. The ABTS radical scavenging activity was calculated as follow:
ABTS scavenging activity $(\%)=100 \times[(\mathrm{Ac}-$

$$
\mathrm{As}) /(\mathrm{Ac}-\mathrm{Ab})]
$$

Where: Ac was the absorbance of the control, As was absorbance of the extract and $\mathrm{Ab}$ was the absorbance of the blank.

\section{DPPH radical scavenging assay}

The DPPH radical scavenging activity of the extracts was determined by measuring the decrease in absorbance of DPPH radical solution in the presence of the extracts. Briefly, $10 \mu \mathrm{l}$ of each extract $(500 \mu \mathrm{g} / \mathrm{ml})$ was added to $190 \mu 1$ of DPPH $(0.1 \mathrm{mg} / \mathrm{ml})$ in 96 well plates. The solution was mixed for $1 \mathrm{~min}$ and incubated at room temperature for $30 \mathrm{~min}$. Then the absorbance of the reaction mixture was recorded at $517 \mathrm{~nm}$ on a microplate reader. Ascorbic acid was used as positive control. The DPPH radical scavenging activity was calculated as follow:

DPPH scavenging activity $(\%)=100 \times[(\mathrm{Ac}-$

$$
\mathrm{As}) /(\mathrm{Ac}-\mathrm{Ab})]
$$

Where: Ac was the absorbance of the control, As was absorbance of the extract and $\mathrm{Ab}$ was the absorbance of the blank.

\section{Identification of the isolates by the $16 \mathrm{~S}$ rRNA sequence}

The most potential bioactive isolates were identified using 16S rRNA gene sequencing. The 16S rRNA gene was amplified with universal primers: $27 \mathrm{f} \quad\left(5^{\prime}-\right.$ AGAGTTTGATCCTGGCT CAG-3') and 1492r (5'- GGTTACCTTGTTACGACTT-3'). The PCR cycling parameters: an initial denaturation at $94^{\circ} \mathrm{C}$ for $5 \mathrm{~min}$ followed by 30 cycles of denaturation at $94^{\circ} \mathrm{C}$ for $1 \mathrm{~min}$, annealing at $56^{\circ} \mathrm{C}$ for $50 \mathrm{~s}$, amplification at $72^{\circ} \mathrm{C}$ for $1.5 \mathrm{~min}$ and a final extension at $72^{\circ} \mathrm{C}$ for $7 \mathrm{~min}$. The 16S rRNA gene sequencing was carried by DNA Analyzer (ABI PRISM 3100, Applied Bioscience). The obtained DNA sequences were removed poor quality ends using BioEdit software v.2.7.5, and then were blasted to sequences in the GenBank database using the Blast search programme (http://www.ncbi.nlm.nih.gov/) to find their highest similarity sequences. The sequences were aligned using the ClustalW algorithm. 
The phylogenetic tree of 16S rRNA sequences was created by the Neighbor-Joining algorithm with 1000 bootstraps using MEGA v.7.0.0

\section{RESULTS}

\section{Isolation of endophytic bacteria from leaves of $\boldsymbol{R}$. stylosa}

From leaves of the plant $R$. stylosa collected from mangrove forest Canh Duong, Phu Loc, Thua Thien Hue, 64 endophytic bacterial strains were isolated and pure cultured, of which 39 strains were isolated from NA medium and 25 strains were isolated from ISP4 medium. Among them, 30 representative strains with different colony morphotypes were selected for preparing ethyl acetate extracts and screening antimicrobial and antioxidant activity.

\section{Antimicrobial activity of the ethyl acetate extracts of the endophytic bacteria}

Ethyl acetate extracts of 30 endophytic bacteria were tested their antimicrobial activity against five pathogenic microorganisms (E. coli ATCC 25922, $P$. aeruginosa ATCC 25923, B. subtilis ATCC 27212, S. aureus ATCC 12222, and $C$. albicans ATCC 7754). The tested results showed that 14 out of 30 endophytic bacteria exhibited antimicrobial activity against at least one reference microorganism with MIC values ranging from 32 to $512 \mu \mathrm{g} / \mathrm{mL}$ (Table 1). Among them, 4 strains showed activity against one reference microorganism, 5 strains showed activity against two reference microorganisms, 4 strains showed activity against 3 reference microorganisms, and only one strain showed activity against 4 reference microorganisms. It was found that isolated strains were more active towards Grampositive bacteria (14 strains) than Gramnegative bacteria (11 strains), whereas number of strains displaying activity against yeast $C$. albicans was lowest (5 strains). Frequencies of the antimicrobial activities against the microbial pathogens were as follows: $B$. subtilis $(23.3 \%)$, S. aureus $(23.3 \%)$, E. coli (20.0\%), P. aeruginosa (16.7\%), C. albicans $(16.7 \%)$

Table 1. Antimicrobial activity $(\mu \mathrm{g} / \mathrm{mL})$ of ethyl acetate extracts from isolated endophytes

\begin{tabular}{|l|c|c|c|c|c|}
\hline \multirow{3}{*}{ Isolates } & \multicolumn{2}{|c|}{ Gram-positive } & \multicolumn{2}{c|}{ Gram-negative } & Yeast \\
\cline { 2 - 6 } & $\begin{array}{c}\text { B. subtilis } \\
\text { ATCC 27212 }\end{array}$ & $\begin{array}{c}\text { S. aureus } \\
\text { ATCC 12222 }\end{array}$ & $\begin{array}{c}\text { P. aeruginosa } \\
\text { ATCC 25923 }\end{array}$ & $\begin{array}{c}\text { E. coli } \\
\text { ATCC 25922 }\end{array}$ & $\begin{array}{c}\text { C. albicans } \\
\text { ATCC 7754 }\end{array}$ \\
\hline RSL-N1 & 64 & 256 & - & 128 & - \\
\hline RSL-N3 & - & - & 256 & - & - \\
\hline RSL-I4 & 32 & - & - & 64 & 256 \\
\hline RSL-I8 & - & 128 & - & - & - \\
\hline RSL-N13 & 256 & - & 128 & 32 & 64 \\
\hline RSL-N14 & 64 & 64 & - & - & - \\
\hline RSL-I16 & - & - & 64 & 64 & 32 \\
\hline RSL-N19 & 512 & 32 & - & - & - \\
\hline RSL-N20 & - & 128 & - & - & - \\
\hline RSL-I23 & 32 & - & - & - & 512 \\
\hline RSL-N24 & - & 64 & 512 & 32 & - \\
\hline RSL-N26 & - & - & 128 & 64 & - \\
\hline RSL-N29 & 128 & - & - & - & 256 \\
\hline RSL-I30 & - & 64 & - & - & - \\
\hline
\end{tabular}


Antioxidant activity of the ethyl acetate extracts of the endophytic bacteria

The antioxidant activity of ethyl acetate extracts of the endophytic bacteria was determined by the ABTS and DPPH radical scavenging assays (Figure 1). The ABTS and DPPH radical scavenging assays showed the extracts of 12 endophytic bacteria exhibited ABTS and DPPH radical scavenging activity with scavenging values from $36.3 \pm 2.6 \%$ to $71.5 \pm 6.6 \%$ and $26.2 \pm 3.3 \%$ to $57.4 \pm 5.8 \%$, respectively. Among them, the ethyl acetate extracts of five bacterial endophytes RSL-N1, RSL-I4， RSL-N13， RSL-I16， RSL-N24 showed the scavenging activity more than $50 \%$. The positive control (ascorbic acid) showed ABTS and DPPH radical scavenging activity with scavenging values of $89.2 \pm$ $6.5 \%$ and $83.4 \pm 6.1 \%$, respectively.

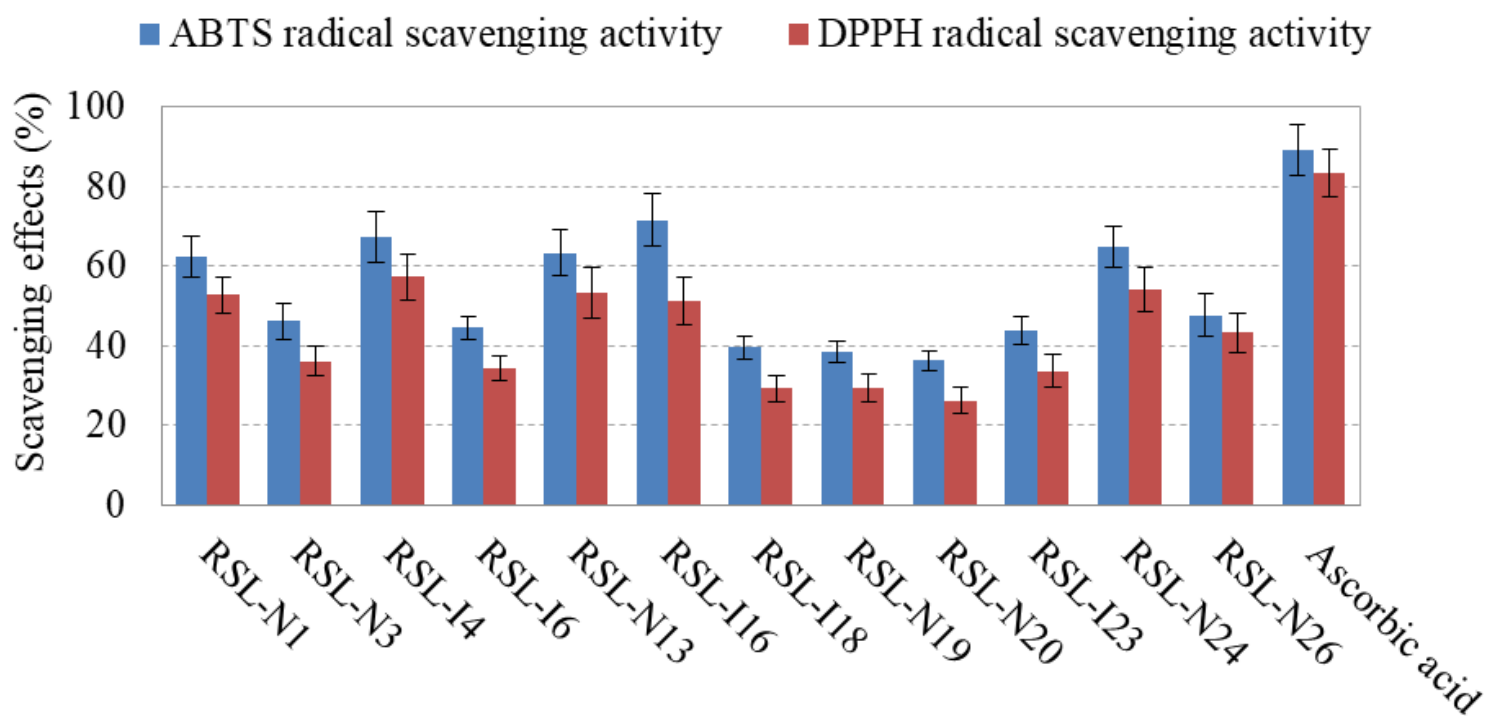

Figure 1. DPPH and ABTS radical scavenging activity of the ethyl acetate extracts

Molecular identification of active bacterial endophytes

The 16S rRNA genes of five endophytic bacteria with highly antimicrobial and antioxidant activities were amplified and sequenced to identify their taxa. The $16 \mathrm{~S}$
rRNA sequences of strains were high similarity $(99-100 \%)$ to that of bacteria on GenBank (Table 2). The phylogenetic analysis revealed that five endophytic bacteria belonged to 4 genera, including Bacillus, Pseudovibrio, Pseudomonas and Streptomyces (Figure 2).

Table 2. The closest sequences of $16 \mathrm{~S}$ rRNA sequences of isolates obtained in NCBI for

\begin{tabular}{|l|c|l|c|}
\hline \multicolumn{1}{|c|}{ Isolates } & Media & \multicolumn{1}{|c|}{ Closest homologs } & Similarity (\%) \\
\hline RSL-N1 & NA & Bacillus pumilus CE92, MK618603 & 100 \\
\hline RSL-I4 & ISP4 & Bacillus licheniformis MSWS30, KX785167 & 99.9 \\
\hline RSL-N13 & NA & Streptomyces viridis BK199, NR_117083 & 99.8 \\
\hline RSL-I16 & ISP4 & Pseudovibrio japonicus WSF2, NR_041391 & 99.6 \\
\hline RSL-N24 & NA & Pseudomonas synxantha IAM 12356, NR_043425 & 99.7 \\
\hline
\end{tabular}




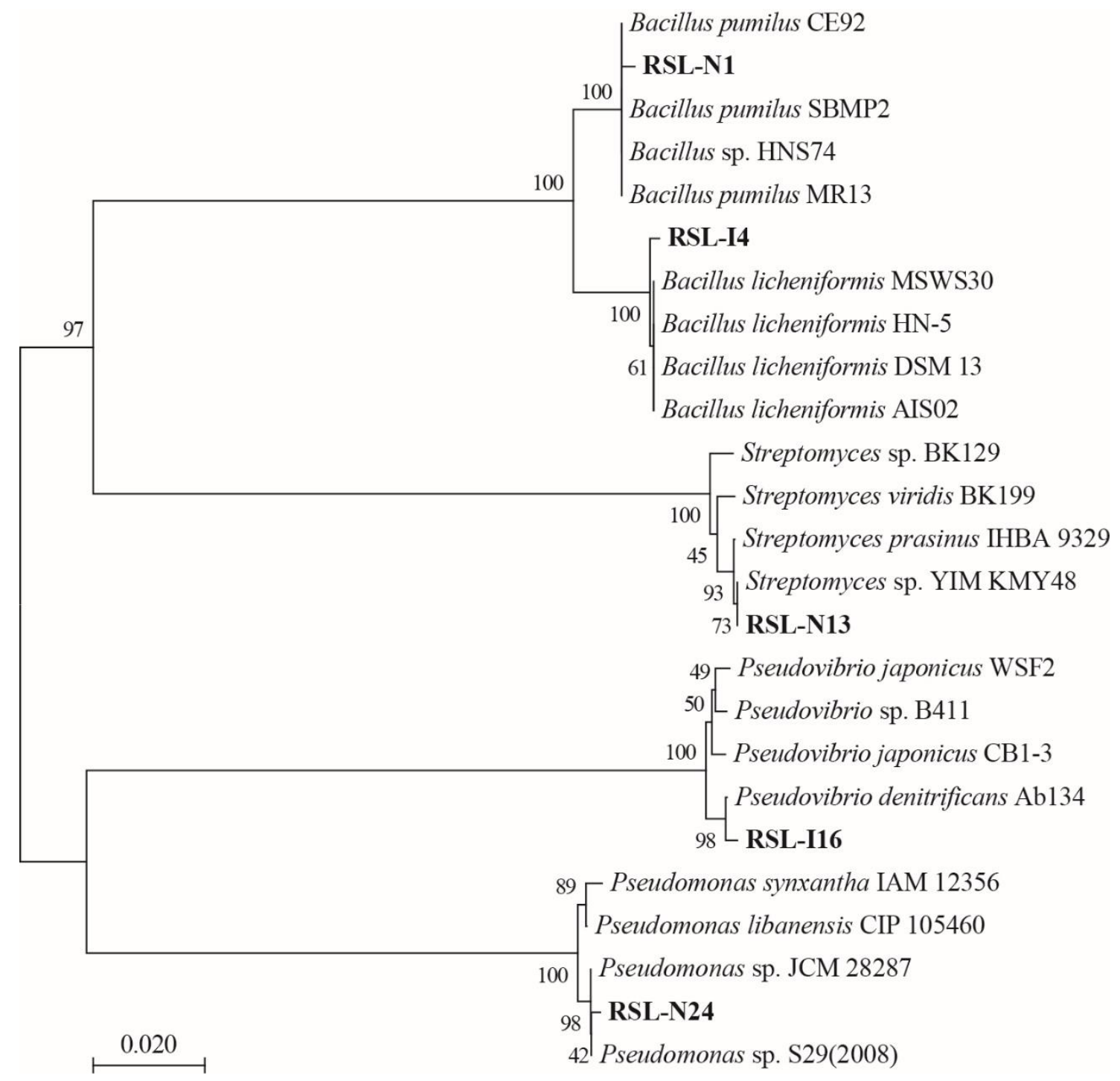

Figure 2. Phylogenetic tree based on 16S rRNA gene sequences of isolates and their closest sequences derived from NCBI

\section{DISCUSSION}

Mangrove plants are considered as an ecological niche for diverse endophytic microorganisms and are potential sources of bioactive compounds. The aim of this study was to isolate endophytic bacteria from the mangrove plant $R$. stylosa and screen antimicrobial and antioxidant activities of ethyl acetate extracts of the isolated endophytic bacteria. The antimicrobial and antioxidant assays in our study revealed endophytic bacteria of $R$. stylosa as potential producers of antimicrobial and antioxidant compounds. Among ethyl acetate extracts of 30 isolated endophytic bacteria, 14 extracts showed antimicrobial activity and 12 extracts showed antioxidant activity. Previous studies have reported that endophytic microorganisms from mangrove plants exhibit a wide range of biological activity, including antimicrobial and antioxidant activities. In respect of the antimicrobial activity, Fareza et al. (2018) isolated two endophytic fungi 
Neopestalotiopsis sp. and Peniophora lycii from leaves of $R$. mucronata. The extracts from two isolated fungi showed antimicrobial activity against E. coli ATCC 25922 and $S$. aureus ATCC 25923 with MIC values from 125 to $500 \mu \mathrm{g} / \mathrm{ml}$. Handayani et al. (2017) isolated 12 endophytic fungi from mangrove plant Sonneratia griffithii. These fungi belonged to two genera Aspergillus and Candida. Among them, the extracts of 10 endophytic fungi exhibited antibacterial activity against $E$. coli and $S$. aureus with zone inhibition from 8.0 to $15.75 \mathrm{~mm}$ at a concentration of $10 \mathrm{mg} / \mathrm{ml}$ extract in DMSO. Eldeen et al. (2014) also isolated 33 endophytic bacteria from five mangrove plants Avicennia lanata, $R$. mucronata, $R$. apiculata, Sonneratia caseolaris, and Xylocarpus moluccensis. Of these, 18 isolated bacteria exhibited antibacterial activity against B. cereus, S. aureus, E. coli, Salmonella typhimurium with MIC values of 19-250 $\mu \mathrm{g} / \mathrm{ml}$. The identification of isolated bacteria revealed that they belonged to genera Bacillus and Staphylococcus. In another study, Nia et al (2017) isolated 12 endophytic bacteria from two mangrove plants $R$. apiculata and Bruguiera gymnorrizha, of which, two fungi Penicillin spp. showed antibacterial activity against Klebsiella pneumonia (Nia et al., 2017). In regard of the antioxidant activity, Rahmawati et al. (2019) isolated six fungi and three bacteria from two mangrove plants Avicennia marina and Xylocarpus granatum. Of these, six fungi and two bacteria showed DPPH radical scavenging activity with $\mathrm{IC}_{50}$ values from $1-19 \mathrm{ppm}$. Zhoe et al. (2018) isolated 225 fungal strains from two mangrove plant $R$. stylosa and $R$. mucronata. Antioxidant assays revealed that the crude extracts of 40 isolated endophytic fungi showed the DPPH and ABTS radical scavenging activities with $\mathrm{IC}_{50}$ values from $0.33 \pm 0.02$ to $14.36 \pm 0.68 \mathrm{mg} / \mathrm{ml}$. Obtained results in our study and the previous studies show that the endophytic microorganisms from mangrove plants are promising sources of antimicrobial and antioxidant agents for pharmaceutical applications.

\section{CONCLUSION}

The present study isolated endophytic bacteria from the mangrove plant $R$. stylosa and screened antimicrobial and antioxidant activity of ethyl acetate extracts from the isolated endophytic bacteria. From leaves of $R$. stylosa, 64 endophytic bacterial strains were isolated, of which the ethyl acetate extracts of 14 isolated endophytic strains showed antimicrobial activity against at least one of reference microorganisms with MIC values from 32 to $512 \mu \mathrm{g} / \mathrm{ml}$. Furthermore, the ethyl acetate extracts of 12 isolated endophytic bacteria showed ABTS and DPPH radical scavenging activity with scavenging values from $36.3 \pm 2.6 \%$ to $71.5 \pm 6.6 \%$ and $26.2 \pm 3.3 \%$ to $57.4 \pm 5.8 \%$, respectively. The identification of five promising endophytic bacteria by $16 \mathrm{~S}$ rRNA sequences revealed that the endophytes to 4 genera, including Bacillus, Streptomyces, Pseudovibrio, Pseudomonas. The obtained results suggest that mangrove endophytes are a potential source of antimicrobial and antioxidant agents.

Acknowledgements: This work was supported by Vietnam Academy of Science and Technology under grant number: ĐL0000.02/19-20.

\section{REFERENCES}

Alvin A., Miller K. I., Neilan B. A., 2014. Exploring the potential of endophytes from medicinal plants as sources of antimycobacterial compounds. Microbiological Research, 169: 483-495.

Ancheeva E., Daletos G., Proksch P., 2018. Lead compounds from mangroveassociated microorganisms. Marine drugs, 16: 319 .

Carroll G., 1988. Fungal endophytes in stems and leaves: from latent pathogen to mutualistic symbiont. Ecology, 69: 2-9.

Dat T. T. H., Hong T. T., Dung T. T. K, Hoa N. P., Cuong P. V., Binh P. T., Dat N. T., Cuc N. T. K., 2018. Screening of antimicrobial producing bacteria associated with sponge and isolation of 
secondary metabolites from selected strain. Proceedings of National Conference on Biotechnology 2018. Publishing House for Natural Science and Technology, Ha Noi, Vietnam, pp. 774-779.

Dat T. T. H., Oanh P. T. T., Tam V. T. T., Anh H. L. T., 2019. Antimicrobial activity of bacteria isolated from the coastal mangrove sediment in Thua Thien Hue. Proceedings of National Scientific Forum 2019: Marine Biology and Sustainable Development. Publishing House of Natural Science and Technology, Hai Phong, Vietnam, pp. 971-980.

Eldeen I., 2014. Isolation of 12 bacterial endophytes from some mangrove plants and determination of antimicrobial properties of the isolates and the plant extracts. International Journal of Phytomedicine, 6: 425-432.

Fareza M. S., Choironi N. A., Harwoko H., Sunarto S., 2018. Antibacterial activity of two isolated endophytic fungi extracts associated with Indonesian mangrove plant Rhizophora mucronata. Pharmaciana, 8: 169-175.

Glick B. R., Penrose D. M., Li J., 1998. A model for the lowering of plant ethylene concentrations by plant growth-promoting bacteria. Journal of Theoretical Biology, 190: 63-68.

Handayani D., Rivai H., Hutabarat M., Rasyid R., 2017. Antibacterial activity of endophytic fungi isolated from mangrove plant Sonneratia griffithii Kurz. Journal of Applied Pharmaceutical Science, 7: 209-212.

Hoai P. T. T., Dat T. T. H., Hong T. T., Cuc N. T. K., Man T. D., Cuong P. V., 2018. Isolation and selection of indigenous antifungal microorganisms against pathogenic fungi of pepper plant in Tay Nguyen. Vietnam Journal of Biotechnology, 16: 385-392.

Hong H. T., Phuong N. N., 2013. The isolation and selection of actinomycete species from Can Gio tropical swamp for their antifungal feature against Fusarium sp. Journal of Science, Ho Chi Minh City University of Education, 51: 59-71.

Kui-Wu W., Shi-Wei W., Bin W0, Ji-Guang W., 2014. Bioactive natural compounds from the mangrove endophytic fungi. Mini-Reviews in Medicinal Chemistry, 14: 370-391.

Manganyi M. C., Tchatchouang C. D. K., Regnier T., Bezuidenhout C. C., Ateba C. N., 2019. Bioactive compound produced by endophytic fungi isolated from Pelargonium sidoides against selected bacteria of clinical importance. Mycobiology, 47: 335-339.

Nia R., Mia M., Oktapiana K., 2017. Antibacterial activity test of endophytic fungus from mangrove plant (Rhizophora apiculata L.) and (Bruguiera gymnorrizha (L.) Lamk.) against Klebsiella pneumoniae ATCC 700603. ICSAFS Conference Proceedings of 2nd International Conference on Sustainable Agriculture and Food Security: A Comprehensive Approach. KnE Life Sciences, West Java, Indonesia, pp. 146-157.

O'Sullivan D. J., O'Gara F., 1992. Traits of fluorescent Pseudomonas spp. involved in suppression of plant root pathogens. Microbiological Reviews, 56: 662-676.

Rahmawati S. I., Izzati F. N., Hapsari Y., Septiana E., Rachman F., Bustanussalam, Simanjuntak P., 2019. Endophytic microbes and antioxidant activities of secondary metabolites from mangroves Avicennia marina and Xylocarpus granatum. IOP Conference Series: Earth and Environmental Science, 278: 012065.

Richardson A. E., Barea J. M., McNeill A. M., Prigent-Combaret C., 2009. Acquisition of phosphorus and nitrogen in the rhizosphere and plant growth promotion by microorganisms. Plant and Soil, 321: 305-339. 
Ryan R. P., Germaine K., Franks A., Ryan D. J., Dowling D. N., 2008. Bacterial endophytes: recent developments and applications. FEMS Microbiology Letters, 278: 1-9.

Sivaramakrishnan S., Gangadharan D., Nampoothiri K., Soccol C., Pandey A., 2006. $\alpha$-amylases from microbial sourcesan overview on recent developments. Food Technology and Biotechnology, 44: 173-184.

Stone J., Bacon C., White J., 2000. An overview of endophytic microbes: endophytism defined. In: Bacon CW \& White J (Eds) Microbial endophytes, CRC Press, Boca Raton, Florida, USA, pp. 3-29.

Thatoi H., Behera B. C., Mishra R. R., Dutta S. K., 2013. Biodiversity and biotechnological potential of microorganisms from mangrove ecosystems: a review. Annals of Microbiology, 63: 1-19.

Tudzynski B., 1997. Fungal phytohormones in pathogenic and mutualistic associations. In: Carroll GC \& Tudzynski P (Eds) Plant Relationships: Part A, Springer Berlin Heidelberg, Berlin, Heidelberg, Germany, pp. 167-184.

$\mathrm{Xu}$ J., 2015. Bioactive natural products derived from mangrove-associated microbes. RSC Advances, 5: 841-892.

Zhou J., Diao X., Wang T., Chen G., Lin Q., Yang X., Xu J., 2018. Phylogenetic diversity and antioxidant activities of culturable fungal endophytes associated with the mangrove species Rhizophora stylosa and $R$. mucronata in the South China Sea. PloS one, 13: e0197359. 